\title{
Comparative Study of Antireflection Coating Materials for Solar Thermal Collectors
}

\section{Fana Filli*, Petros Gebray and Ashenafi Kebedom}

School of Mechanical and Industrial Engineering, Ethiopian Institute of Technology-Mekelle, Mekelle University, Ethiopia (*fana.filli@mu.edu.et).

\begin{abstract}
Locally available absorber and antireflection coating materials for solar thermal collectors have been assessed and tested for performance compared to ordinary commercial black paint used in solar water heaters and solar cookers. Absorber plates made of aluminum and iron sheet metals coated with blackboard paint, commercial black paint, and black ABRO spray were prepared. These materials were tested for thermal performance on a natural circulation flat plate solar water heater and plastic bottles. Comparison has been made separately for both absorber material and coating materials which showed that the iron sheet and black ABRO spray to have the highest absorptance. On a clear sky radiation of $973.5 \mathrm{~W} / \mathrm{m}^{2}$, a maximum stagnation temperature of $99.2^{\circ} \mathrm{C}$ and $107.5^{\circ} \mathrm{C}$ is achieved on the black ABRO spray painted aluminum sheet metal and iron sheet metal respectively. This is because ABRO black paint has the highest absorptance for wavelengths of below $2.5 \mu \mathrm{m}$ and low thermal emittance for wavelengths above $2.5 \mu \mathrm{m}$. During the testing of solar water heaters, an increase in temperature of $14.9^{\circ} \mathrm{C}$ at the outlet from absorber plate and $7.5^{\circ} \mathrm{C}$ at the surface of storage tanker has been achieved when using ABRO black spray. This is attributed to the highest absorptance for wave lengths of below $2.5 \mu \mathrm{m}$ and low thermal emittance for wave lengths above $2.5 \mu \mathrm{m}$ of ABRO black paint. As can be concluded, iron sheet metal which is cheap and easily available is best for solar thermal applications and provides significant benefit in cost reduction. Furthermore, the cost for ABRO black paint is similar to other coating materials and it can easily be applied on the surface of absorber materials.
\end{abstract}

Keywords: Thermal collectors, Antireflection, Absorptance, Ethiopia.

\section{INTRODUCTION}

Solar thermal collectors are utilized for direct conversion electromagnetic radiation from sunlight in to thermal energy (Duffie and Beckman, 1980). To enhance the conversion of sunlight into heat, antireflection coating materials are deposited on the surface of a collector. There are different types of coating materials and mechanisms by which coating materials are deposited (Friz and Waibel, 2003). Usually, black coating is preferred for efficient conversion of solar energy. The materials used in selective surface range from the inexpensive steel or aluminum plate coated with black paint to very efficient chromium nickel plated copper panels (Madhukeshwara and Prakash, 2012). Depending upon the cost, durability and performance, 
antireflection materials are applicable in solar thermal collectors and greenhouses.

Solar thermal collector coating techniques can be divided into two types, selective and nonselective (Friz and Waibel, 2003). Non-selective coatings are characterized with high absorbance and high emittance, which is found in all locally, manufactured solar collectors. Selective coatings are deposited using chemical or electrical process. These anti-reflection coatings have high absorbance and low emittance. Efficient absorbers have high absorption of irradiation and low emission of heat radiation.

The selective coating materials are very efficient, durable, and highly resistant to humid and oxidizing conditions, and extreme temperatures and at the same time, able to retain its selective properties. However, a black painted steel sheet metal costs less and is readily available in local market. Nonetheless, they have a much lower efficiency and high deterioration rate due to harsh environmental conditions.

Solar water heating system (Riahi and Taherian, 2011; Nosa et al., 2013), disinfection of water for domestic use (Akintola and Sangodoyin, 2015) and solar cooking (Mulu et al., 2013; Asfafaw et al., 2014) are some of the most common and simple applications of solar thermal collectors. Typical solar water heating system applications are domestic hot water and industrial process heat supply, solar desalination, solar refrigeration and solar thermal power generation. The most commonly used types of systems are thermosiphon (natural circulation) active systems categorized under the direct circulation and indirect water heating system and integrated collector storage system.

Thermosiphon (natural circulation) solar water heating systems uses natural convection temperature difference at the absorber inlet and outlet to transport the fluid from absorber into storage. In the present case, a natural circulation process is established because the heated water expands decreasing its density and the cold water forces the water to flow into the storage section. Such solar water heaters have been extensively analyzed both experimentally and analytically (Soteries, 2004). The integrated collector storage system (ICS) uses the surface of the storage tank as an absorber. Such systems need no control and water is drawn from the top part of the storage and make up water is placed on top of the ICS system on a separate container. The active systems categorized under the direct circulation and indirect circulation system use pump to transport the fluid from the collector to the storage and back to the collector. In direct circulation solar water heating system, the fluid is directly heated as it passes through the 
collector. However, in indirect solar water heating system, a heat transfer fluid such as high temperature oil is used as an absorber and a heat exchanger integrated for heat exchange between the heat transfer fluid and water.

Despite the fact that solar energy is free, solar water heaters are not widely used throughout the world due to their high investment cost (Gautam et al., 2017). In addition, various industrial surveys show that up to 24 percent of all industrial heat, directly used in industrial processes, is at temperatures below $180^{\circ} \mathrm{C}$. In several industries, 100 percent process heat requirement is below $180^{\circ} \mathrm{C}$, which can be supplied economically by evacuated tube collectors and solar concentrators (Garg and Prakash, 2006). However, Ethiopia has poor market infrastructure and financing for renewable energy technologies (National workshop, 2014). Hence, industries for the manufacture of renewable energy harnessing technologies are almost nonexistent. Many of the solar thermal collectors available are imported from other counties.

Researchers have focused on the improvement of the existing solar water heaters and solar cookers by maximizing the collector, using reflectors (Mulu et al., 2013), improving thermal performance using cover glasses with low emissivity (Ghosh et al., 2017), and changing the geometry of the collector materials (Vyas and Punjabi, 2014; Kundu, 2002). However, the studies are limited on the locally and readily available coating materials (AlShamaileh, 2010).

Therefore, the present paper provides the results of a comparative study conducted on the locally available antireflection coating materials for solar thermal collectors and thermal performance tests for selected paints. Further, the aim of the work is to identify locally available absorber and coating materials and perform experimental comparative study for solar thermal application.

Aluminum and iron sheet metals are good conductors and readily available in the market. The approach used in the present case is that the samples of absorber plate are prepared from aluminum and iron sheet metals coated with locally available plastic paints, spray and blackboard paints. The coated specimens are compared by estimating the useful heat gained by each specimen. Modifications are also tried to increase the efficiency and performance of locally made solar thermal collectors, and further to contribute towards the market penetration of locally manufactured solar thermal collectors.

\section{MATERIALS AND METHODS}

A careful assessment was made on the locally available collector and coating materials suitable (C) CNCS, Mekelle University 
for solar thermal application. Choice of materials was made based on their availability, cost and ease of manufacturing. Hence, aluminum and iron sheet metals for absorber plate and blackboard paint, commercial black paint and ABRO black spray were selected for detailed testing and analysis.

Then, a careful study of the performance of bare and coated aluminum and iron sheet metals is made in achieving stagnation temperature. And the performance of the available collectors and coating materials are experimentally investigated by using solar water heaters available in the solar demonstration center of Mekelle University $\left(13.47^{\circ} \mathrm{N}, 39.47^{\circ} \mathrm{E}\right)$. Systematic analysis of the present research work included: preparation of collector cells of aluminum and iron sheet metal, preparation of plastic bottles painted with coating materials and testing of solar water heaters using the different coating materials available.

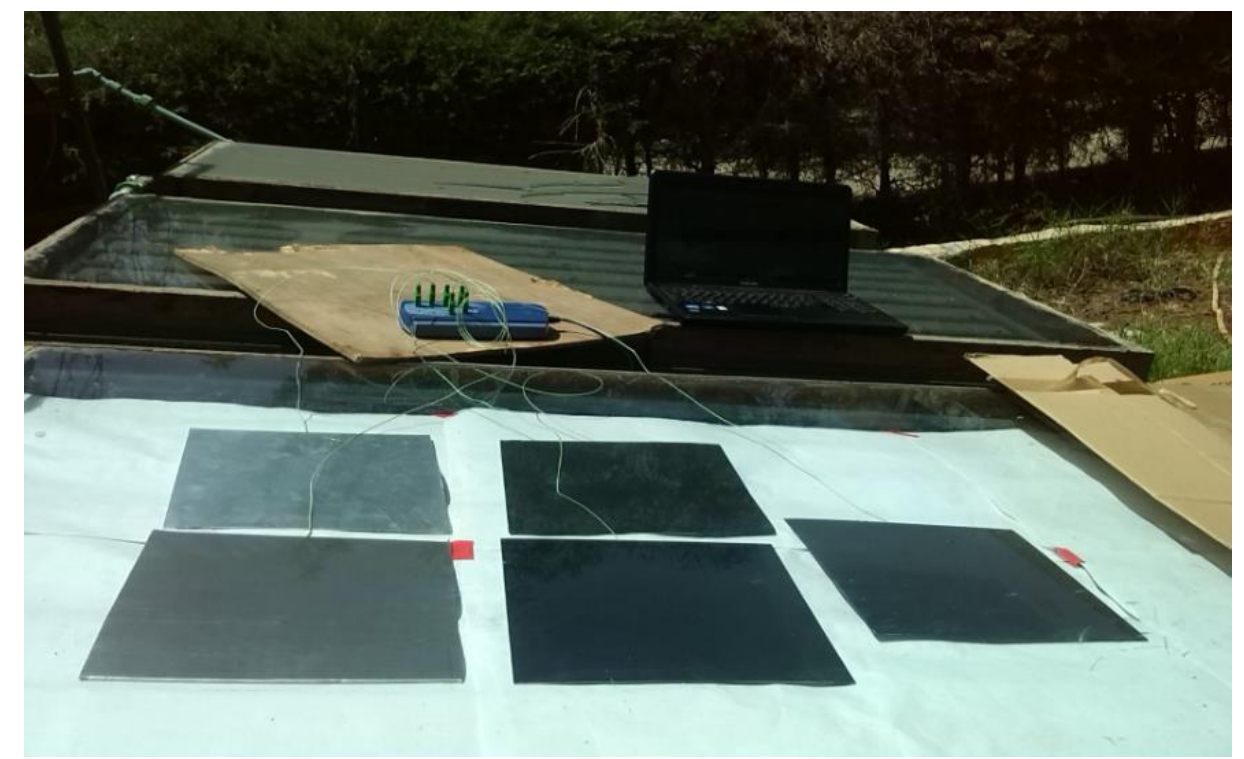

Figure 1. Flat plate specimen of aluminum and iron sheet metals.

An outdoor experimental set up (Figs 1 to 3) has been designed for testing the performance of solar thermal collectors and antireflection coating materials. Absorber materials with dimension of $250 \mathrm{~mm} \times 250 \mathrm{~mm}$ and thickness of $2 \mathrm{~mm}$ (Fig 1) are placed in a solar collector box covered with a $4 \mathrm{~mm}$ clear glass. Five plates are prepared so that three of the plates are painted with blackboard paint, commercial black paint and ABRO black spray paints and the two plates are bare aluminum and iron sheet metals. 


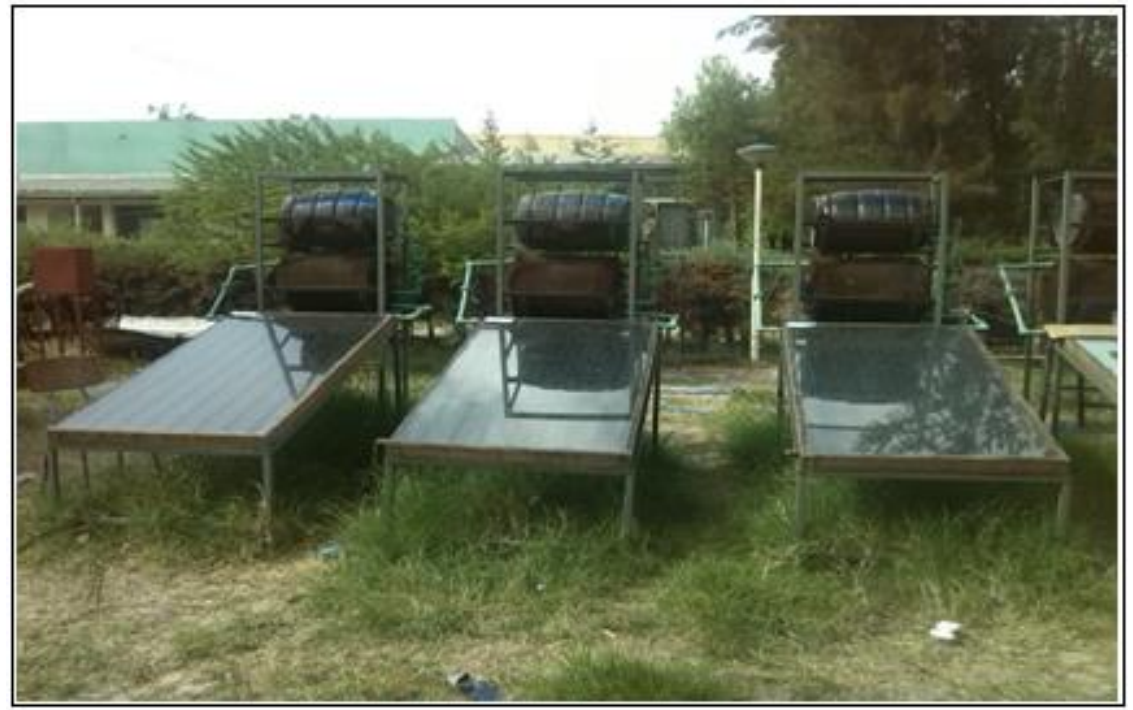

Figure 2. Flat plate solar water heaters.

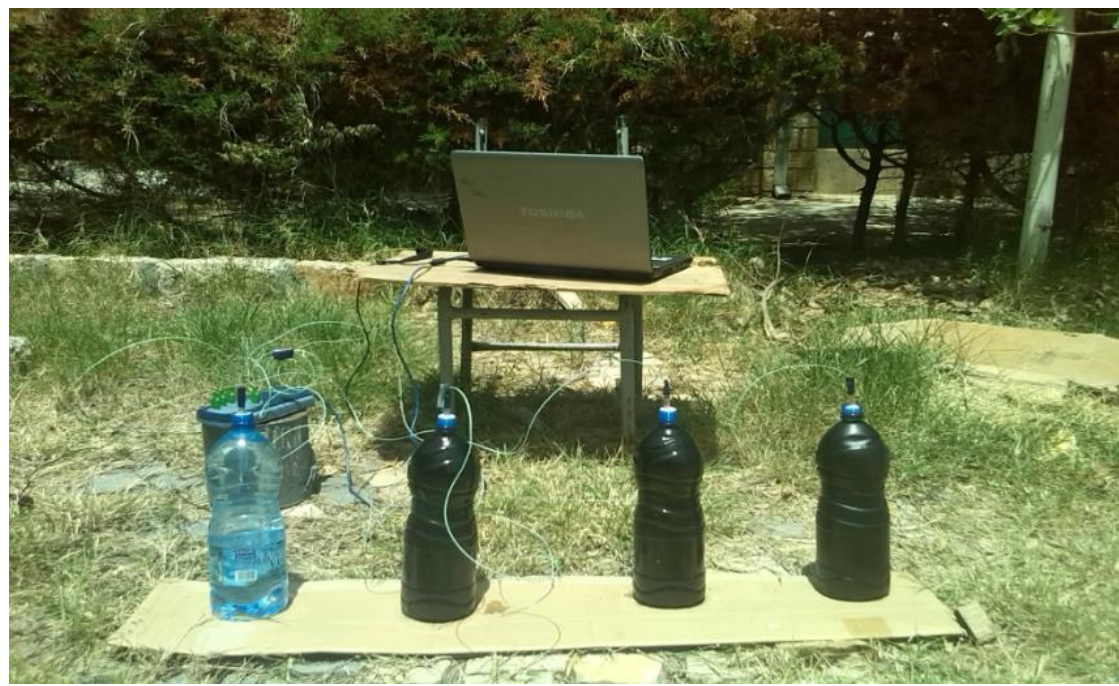

Figure 3. Black painted and control plastic bottles.

Further investigations are conducted on solar water heaters (Fig 2) and plastic bottles in figure 3. The selected coating materials were applied in existing solar water heaters at the solar demonstration center of Mekelle University. The solar water heaters consist of flat plate collectors with eight $22 \mathrm{~mm}$ diameter galvanized iron tubes place in a wooden box and covered with $4 \mathrm{~mm}$ thick clear glass. The total collector area of the solar water heater is $1.68 \mathrm{~m}^{2}(935 \mathrm{~m} \times 1805 \mathrm{~mm})$. A storage tank of 60litre plastic containers were used to store water. 


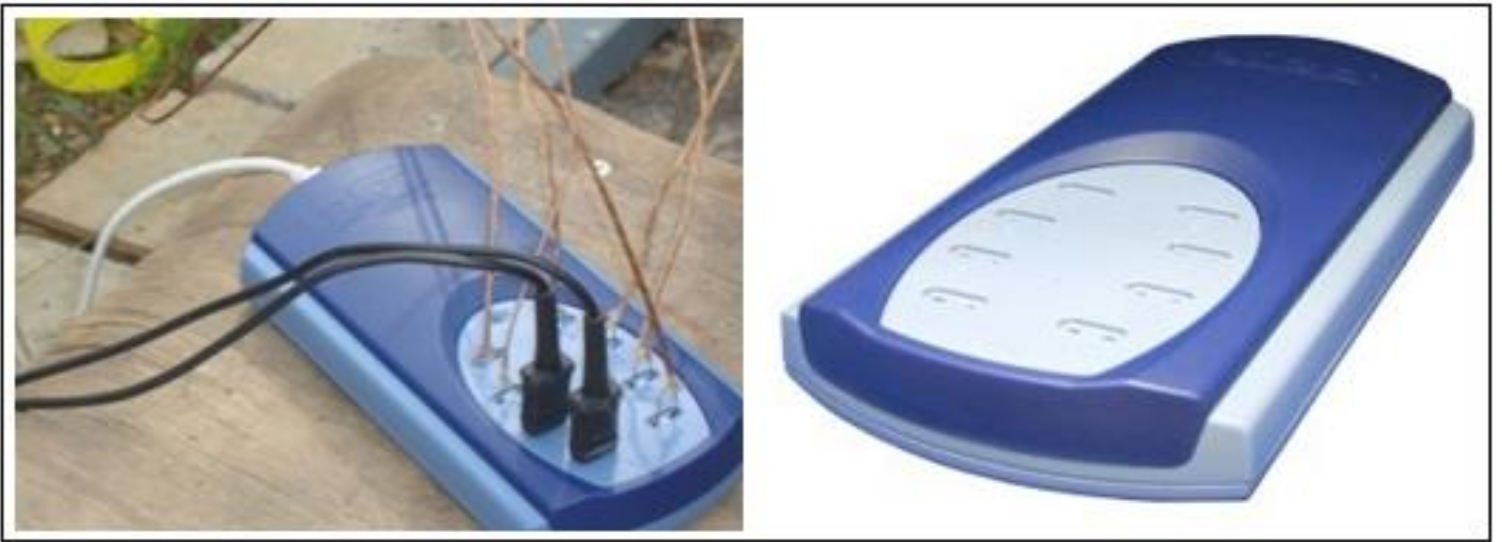

Figure 4. Temperature measuring USB TC-08 data logger.

The performance measurement of the experimental set up is monitored using temperature and radiation measurements devices. The monitoring system consists of K-type thermocouple used together with TC-08 thermocouple data logger (Fig 4). The USB TC-08 is a temperature and voltage logger designed to support multiple thermocouples. With the accompanying PicoLog software, the unit can be used with any laptop or PC. The USB TC-08 can measure and record upto 8 thermocouples. K-type thermocouples were attached around main components by soldering. It was then connected to a laptop where the data is recorded and saved.

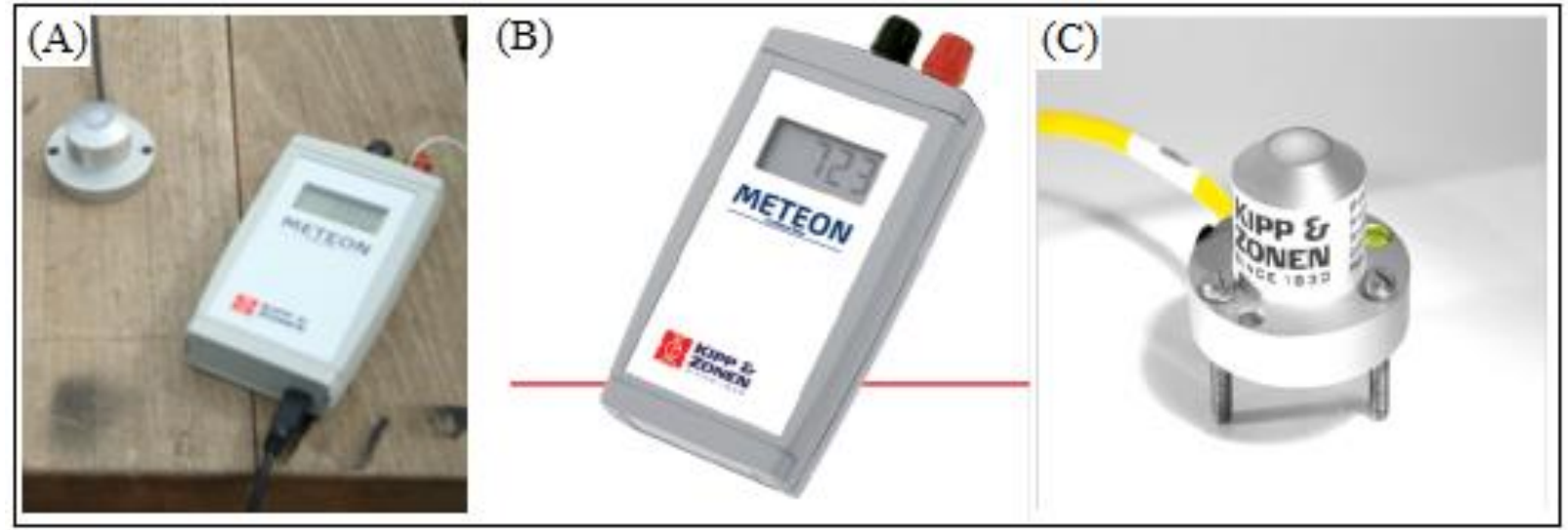

Figure 5. A) Solar irradiance sensor, B) Data logger, and C) SP Lite Silicon Pyranometer.

The SP LITE, a Silicon pyranometer (Fig 5) is used to measure global solar radiation (diffuse and beam). SP LITE is designed for use with the METRON handheld display and data logger. The sensor sensitivity is programmed into the METRON such that the data readout will show (C) CNCS, Mekelle University 
calibrated engineering units rather than volts. The sensor receives solar energy from the entire hemisphere in its view and produces a small voltage output that can be converted into the irradiance in watt per square meter $\left(\mathrm{W} / \mathrm{m}^{2}\right)$.

\section{RESULTS AND DISCUSSION}

\subsection{Comparison of Bare Aluminum and Iron Sheet Metals}

Both aluminum and iron sheet metals were first tested for thermal performances by exposing them to clear sky radiation. The temperatures were recorded in ten minutes interval. Figures 6 and 7 shows the test results of both aluminum and iron sheet metals on June 3, 2016 on sunny day. As figure 6 indicates, both the absorber materials show sharp increase in temperature in 15 minutes and the response time is short and maintain their stagnation temperature at an average of $100^{\circ} \mathrm{C}$ and $80^{\circ} \mathrm{C}$ for iron and aluminum sheet metal respectively. After stagnation temperature, the temperature difference between the two absorber plates remained at an average of $18^{\circ} \mathrm{C}$.

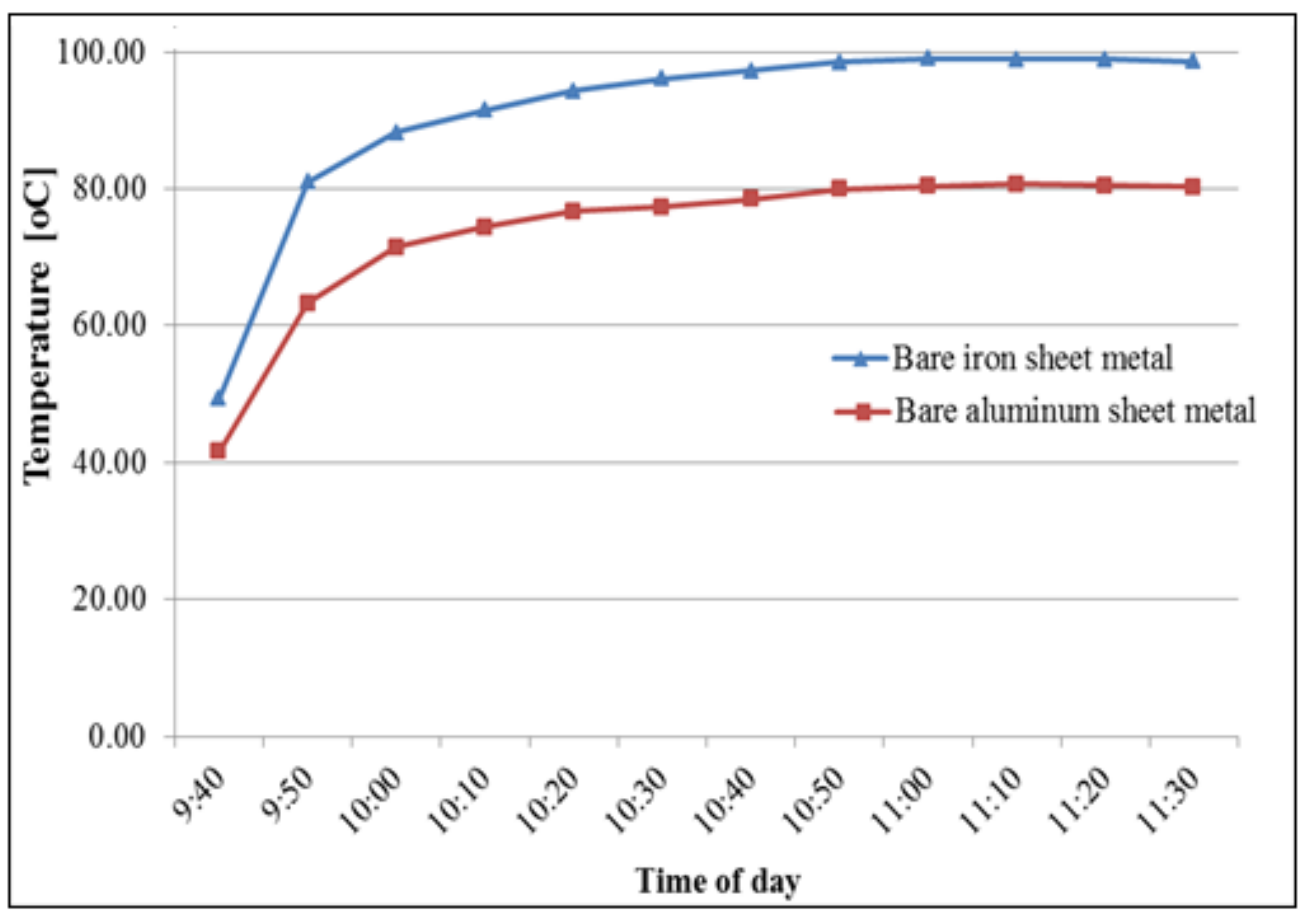

Figure 6. Temperature of bare aluminum and iron sheet metal. 


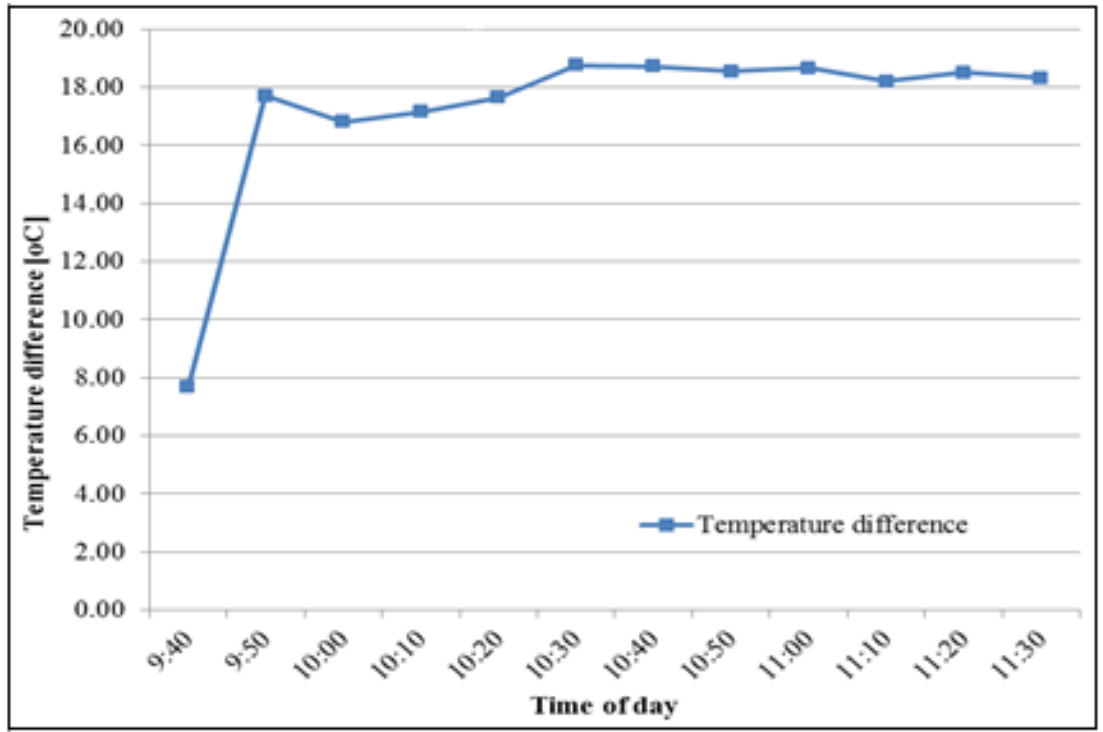

Figure 7. Temperature difference between bare aluminum and iron sheet metal.

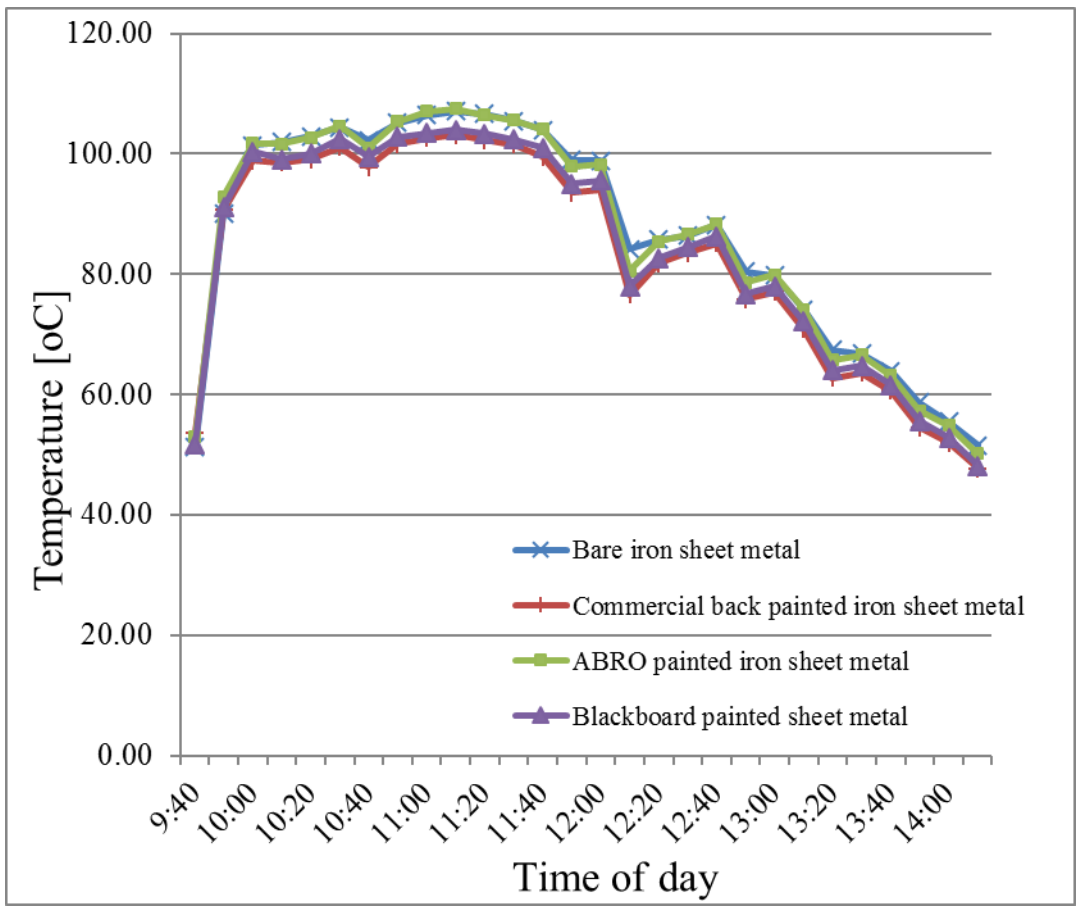

Figure 8. Temperature of bare and coated iron sheet metal.

\subsection{Comparison of Bare and Coated Iron Sheet Metals}

To study the performance of the antireflection coating materials and compare the results with bare iron sheet metal, an experimental set up of four $250 \mathrm{~mm} \times 250 \mathrm{~mm}$ sheet metal cells were prepared and coated with blackboard paint, commercial black paint and black ABRO stray (Fig 1). The period of testing was on June 04, 2015 from 9:30AM to 2:30PM and during the tests (C) CNCS, Mekelle University 
temperature and radiation measurements were taken. Figures 8 and 9 show that the variation of temperatures for all the four specimen of iron sheet metal. From these plots it can be seen that the temperature difference between bare and ABRO painted sheet metals have higher stagnation temperatures compared to commercial black paint and black board paints.

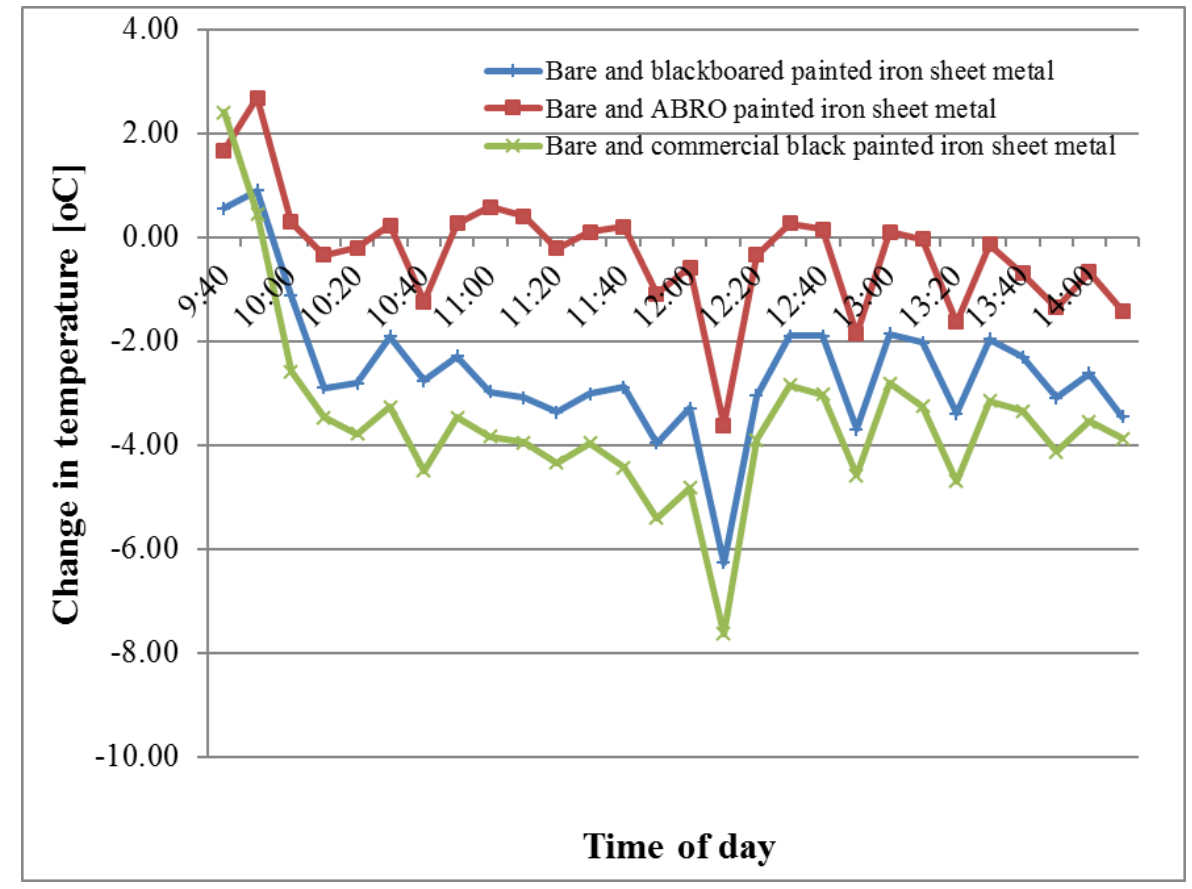

Figure 9. Temperature difference between bare and coated iron sheet metal.

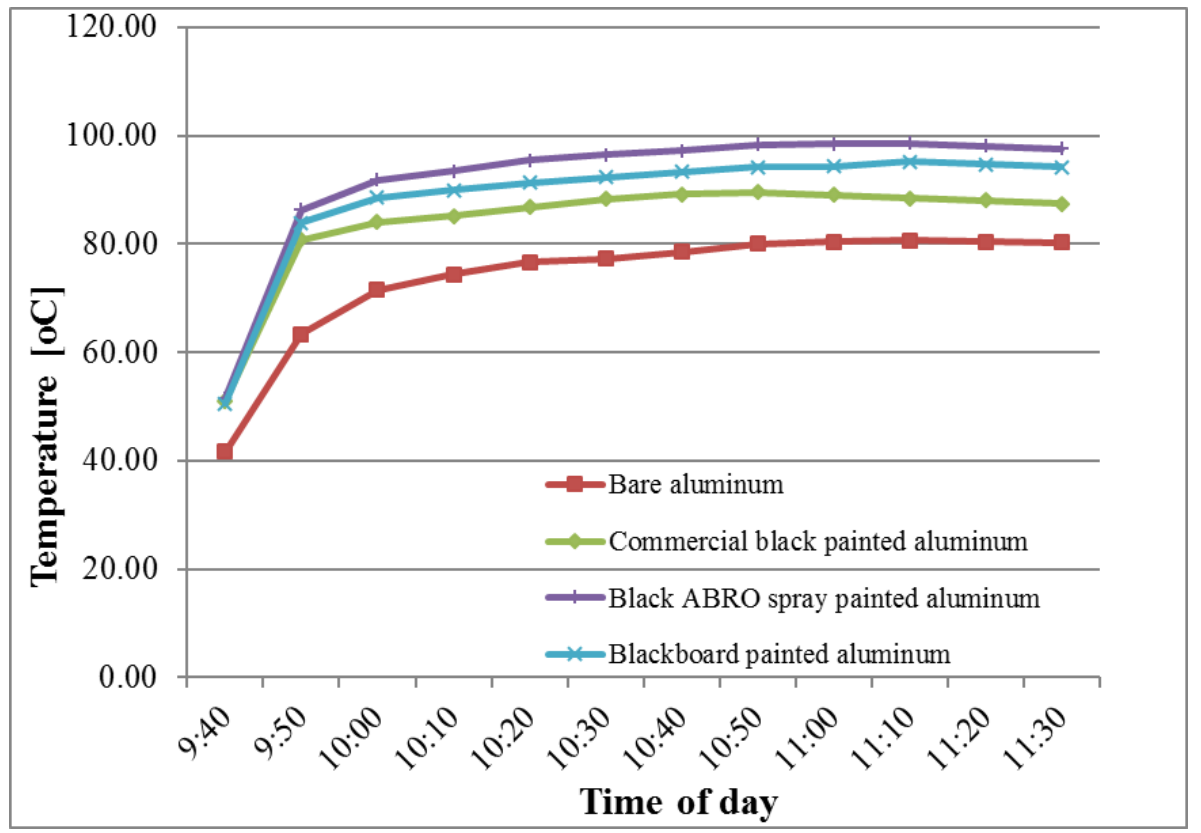

Figure 10. Temperature of bare and coated aluminum sheet metal. 


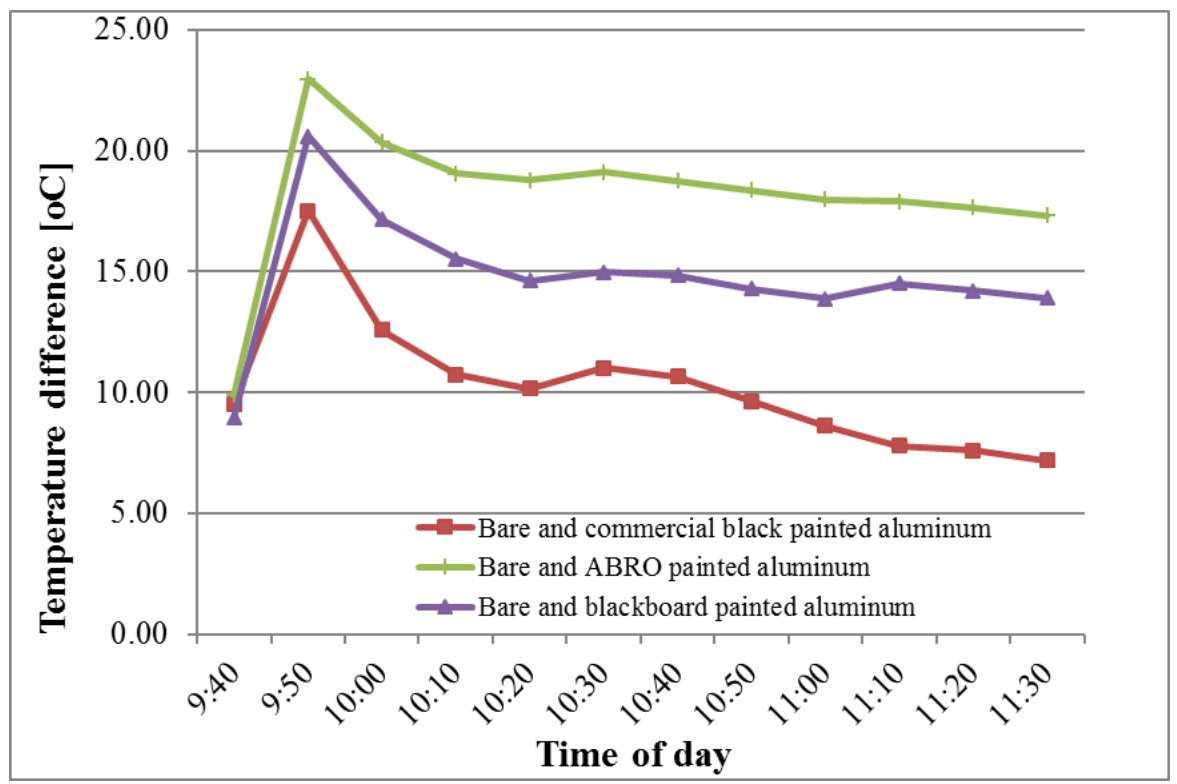

Figure 11. Temperature difference between bare and coated aluminum sheet metal.

\subsection{Comparison of Bare and Coated Aluminum Sheet Metals}

Figures 10 and 11 show the testing results for bare and coated aluminum sheet metals that depicts the variation in the four specimens. From these plots it can be seen that the temperature of black ABRO spray painted aluminum metal has the highest stagnation temperature (Fig 10) and an average temperature difference of $18.2^{\circ} \mathrm{C}$ between a bare and black $\mathrm{ABRO}$ spray painted aluminum.

\subsection{Antireflection Coating Materials on Flat Plate Solar Water Heaters}

The performance of antireflection coating materials were finally made on the existing solar water heaters available at the solar demonstration center of Mekelle University. These flat plate solar water heaters are designed to perform in a natural circulation system. The absorber material of the water heaters is coated with blackboard paint, commercial black paint and black ABRO spray and the wooden box is covered with a $4 \mathrm{~mm}$ clear glass. Temperature measurements are taken at the outlet from the collector and at the surface of the storage tanker. The variation of temperature along the solar water heaters is shown in figure 12 and 13. During the testing of solar water heaters, an increase in temperature of $14.9^{\circ} \mathrm{C}$ at the outlet from absorber plate and $7.5^{\circ} \mathrm{C}$ at the surface of storage has been achieved when using ABRO black spray. 


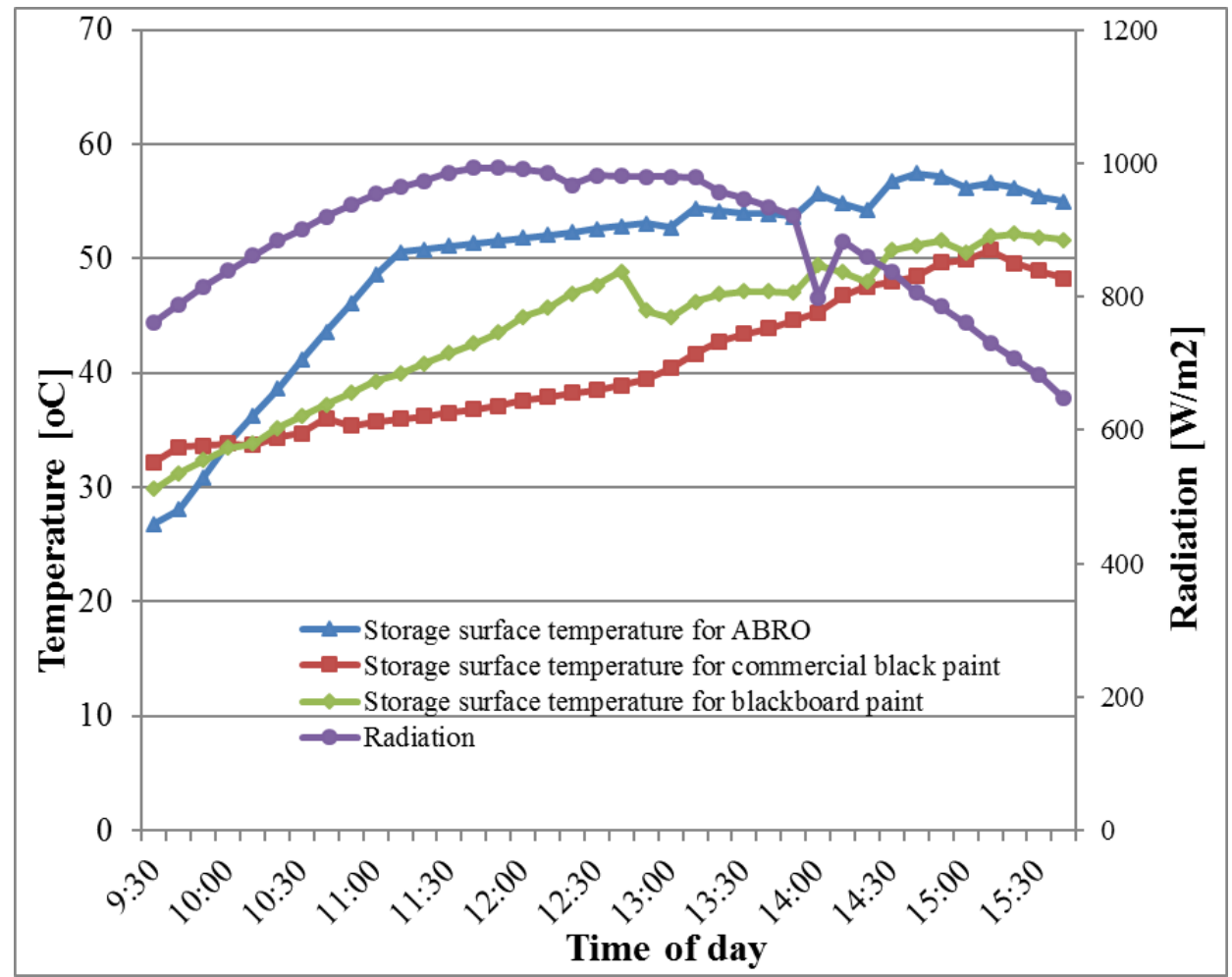

Figure 12. Storge surface temperature of solar water heater and radiation.

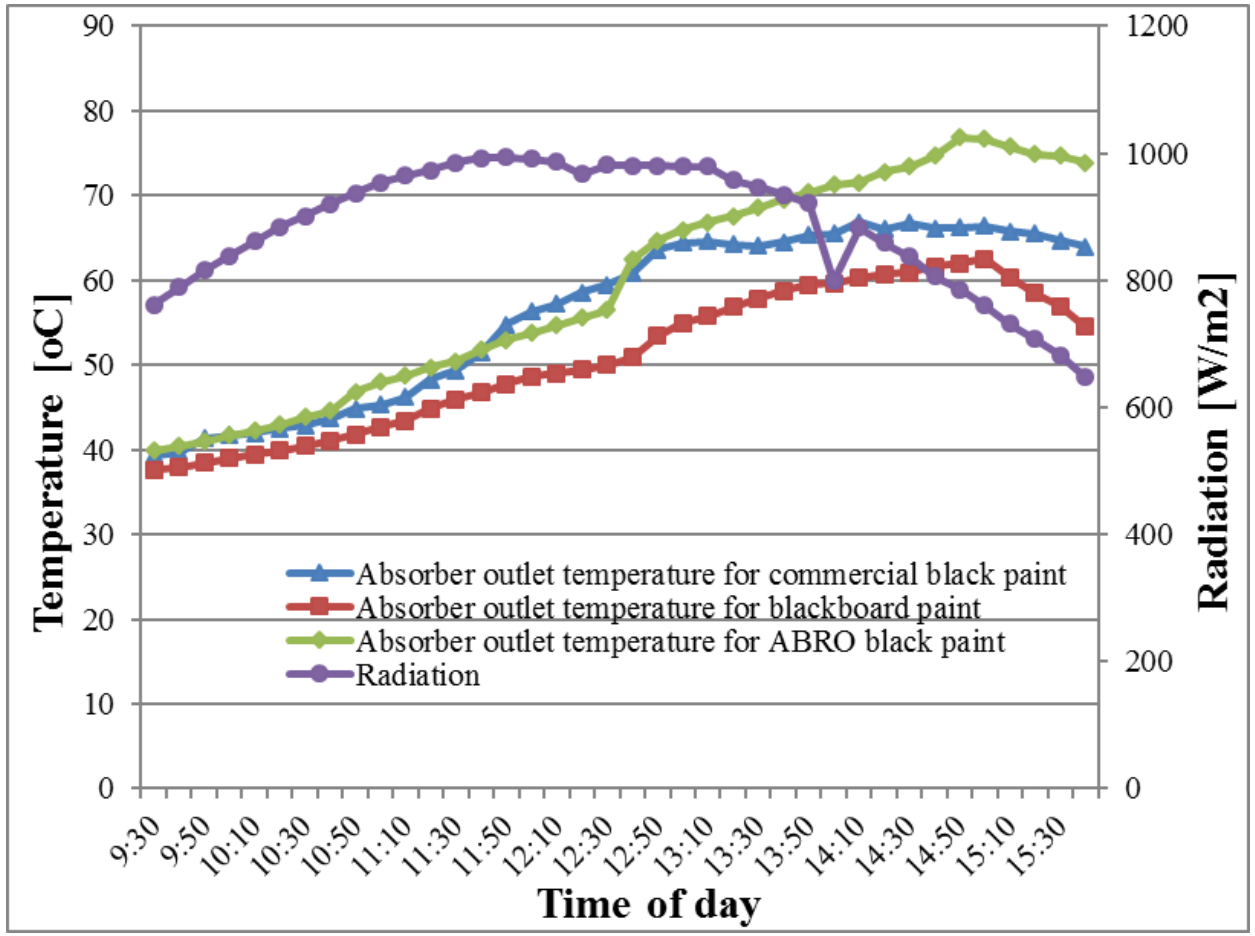

Figure 13. Absorber outlet surface temperature of solar water heater and radiaion. 


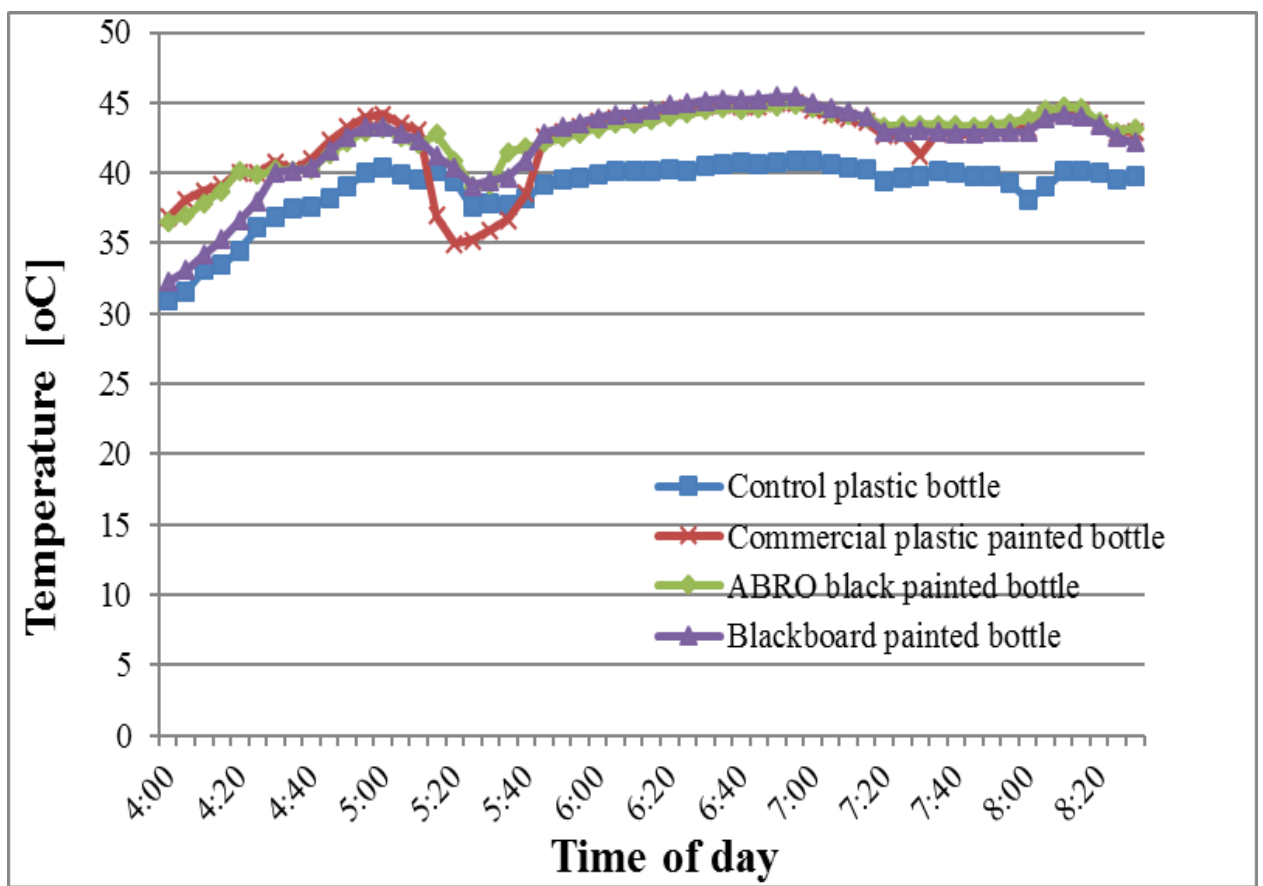

Figure 14. comparision of bare and coated plastic bottles.

\subsection{Antireflection Coating Materials in Plastic Bottles}

An extensive testing has been made to make engough comparision between the locally abailable antireflection coating materials. The last experiment was to conduct the performance of coating material in 2 litre capacity plastic bottles. Figure 14 shows the comparision of bare plastic bottle and coated plastic bottles.

\section{CONCLUSIONS AND RECOMMENDATIONS}

The objective of this research was to conduct a comparative study of locally available antireflection coating materials for solar thermal collectors. It aimed to carryout thermal performance tests of selected coating materials. Some local paints are used for surface coatings such as blackboard, commercial black paint, and ABRO black spray. Experimental results have shown that the solar water heater collector plate, iron sheet metal, aluminum plate and plastic bottles painted by ABRO black spray had the highest temperature and hence the highest absorptance for solar radiation. On a separate test set up comparison of available absorber materials has been conducted. The experimental test showed bare aluminum sheet metal and iron sheet metal a maximum stagnation temperature of $80^{\circ} \mathrm{C}$ and $100^{\circ} \mathrm{C}$ respectively. Over a period of 
time, the average temperature difference between the two absorber materials was found $18^{\circ} \mathrm{C}$. This can give an advantage of $18 \%$ increase in temperature of the fluid and an early usage of hot water for domestic or industrial applications.

As can be concluded, iron sheet metal which is cheap and easily available is best for solar thermal applications and provides significant benefit in cost reduction. Furthermore, the cost for ABRO black paint is similar to the other coating materials and it can easily be applied on the surface of absorber materials. As coating materials are always exposed to the sun, coating materials deteriorate over time due to the cyclic heating and cooling throughout the day and night. Therefore, further study on the durability and reliability of the coating materials is needed

\section{ACKNOWLEDGEMENTS}

We would like to thank Mekelle University for providing us the budget with all the necessary resources and manpower and also acknowledge the reviewers for their valuable inputs.

\section{REFERENCE}

AlShamaileh, E. 2010. Testing of a new solar coating for solar water heating applications. Solar Energy, 84:1637-1643.

Asfafaw H. T., Mulu B. K \& Ole J. N. 2014. Solar Powered Heat Storage for Injera Baking in Ethiopia. Energy Procedia, 57:1603-1612.

Akintola, O. A \& Sangodoyin, A. Y. 2015. Design, Development, and Performance Evaluation of Solar Heating System for Disinfection of Domestic Roof-Harvested Rainwater. International Scholarly Research Notices, doi: 10.1155/2015/529527.

Duffie, J. A \& Beckman, W. A. 1980. Solar engineering of thermal processes. ISBN: 978-0-47087366-3, Wiley, pp.236-240.

Friz, N \& Waibel, F. 2003. Coating materials. Springer Series in Optical Sciences. 88:105-130.

Garg, H.P \& Prakash, J. 2006. Solar energy for industrial process heat, in: Solar energy fundamentals and applications. Tata McGraw-Hill, ISBN 0-07-463631-6, pp.229-230.

Gautam, A., Chamoli, S., Kumar, A \& Singh, S. 2017. A review on technical improvements, economic feasibility and world scenario of solar wáter heating system. Renewable and Sustainable Energy Reviews, 68: 541-562.

Ghosh, S. S., Biswas, P. K \& Neogi, S. 2017. Thermal performance of solar cookers with special 
cover glass of low-e antimony doped indium oxide (IAO) coating. Applied Thermal Energy, 113: 103-111.

Kundu, B. 2002. Performance analysis and optimization of absorber plates of different geometry for a flat-plate solar collector: a comparative study. Applied Thermal Engineering, 22: 999-1012.

Madhukeshwara, N \& Prakash, E. S. 2012. An investigation on the performance characteristics of solar flat plate collector with different selective surface coatings. Energy and Environment, 3:99-108.

Mulu, B. K., Paintin, J., Anwar, M., Asfafaw, H., Meseret, T \& Biniam, G. 2014. Theoretical and experimental comparison of box solar cookers with and without internal reflector. Energy Procedia, 57:1613-1622.

Nosa, A. O., Ikponmwosa, O \& Julius, J. 2013. Design and construction of a solar water heater based on the thermosyphon principle. Journal of Fundamentals of Renewable energy and Applications, 3:1-8.

National Workshop. 2014. Dissemination of Solar Energy Technologies in Ethiopia: Successes, Challenges and Opportunities. Proceeding volume, Addis Ababa, Ethiopia, (www.hoarec.org/docs/ESEF\%20Proceedings_HD.pdf).

Riahi, A \& Taherian, H. 2011. Experimental investigation on the performance of thermosyphon solar water heater in the south Caspian Sea. Thermal Sciences, 15:447-456.

Soteries, A. Kalogirou, 2004. Solar thermal collectors and applications. Progress in Energy and Combustion Science, 30:231-295.

Vyas, S \& Punjabi, S. 2014. Thermal performance testing of a flat plate solar air heater using optical measurement technique. International Journal of Recent Advances in Mechanical Engineering (IJMECH), 3(4):69-84. 